\title{
Anthocyanin Stability and Silage Fermentation Quality of Colored Barley
}

\author{
Tae Hwa Song ${ }^{1}$, Ouk kyu Han², Tae II Park', Dae Wook Kim², Chang Yoon ${ }^{3}$, \\ Kee Jong $\mathrm{Kim}^{1}$ and Ki Hun Park ${ }^{1}$ \\ ${ }^{1}$ Dept. Rice and Winter Cereal Crop, NICS, RDA, Iksan 570-080, Korea, \\ ${ }^{2}$ National Institute of Crop Science, RDA, Suwon 441-857, Korea, \\ ${ }^{3}$ Dept. Animal bio, Chanbuk National University, Jeonju, 561-756, Korea
}

\begin{abstract}
This study was conducted to observe the fermentative quality and anthocyanin content in whole crop colored barley silage during storage periods and anthocyanin stability in in vitro ruminal fluid. Silages of colored barley cultivar "Boanchalbori" and normal barley cultivar "Yuyeonbori" were stored during 0, 2, 4, 6 , and 12 months. The in vitro ruminal fluid was fermented for $0,6,12,24$, and 48 hrs. For the feed value, crude protein of colored barley silage was slightly increased in the silage compared to that of normal barley silage, and being increased up to 2 months after ensiling and thereafter maintained at the similar level. Neutral detergent fiber (NDF) and acid detergent fiber (ADF) contents of both the barley significantly increased by prolonged storage of 2 months $(\mathrm{p}<0.05)$, but they were maintained at the constant level after 2 months of storing silage. Whereas TDN (total digestible nutrients) contents of them were decreased by the prolonged storage of 2 months $(\mathrm{p}<0.05)$, then maintained at the constant levels. The fermentative quality and $\mathrm{pH}$ values in both the barley silages were slightly decreased during the storage time. Lactic acid and acetic acid contents were increased during prolonged storage period, but not significantly different among treatments. Butyric acid was not detected. In the colored barley silage, $\mathrm{pH}$ value showed slightly lower compared to that of the normal barley silage but not significant, and lactic acid content was significantly higher than the normal barley silage $(\mathrm{p}<0.05)$. The total anthocyanin content in the whole crop colored barley silage decreased to $42 \%$ after 2 months of ensilage, however maintained at the constant level until 12 months of ensilage. In the case of anthocyanin stability on in vitro ruminal fluid digestion, the $\mathrm{pH}$ value of the ruminal fluid was slightly lower at $6,12,24,48 \mathrm{~h}$ incubation time and the content of anthocyanin was at similar levels. These results indicated that the colored barley showed higher fermentation quality, and total anthocyanin content was maintained stable at $42 \%$ level of the first value in storing silage. As the anthocyanin had higher stability in the ruminal fluid, the colored barley has a potential as functional feeds for Ruminants.
\end{abstract}

(Key words : Anthocyanin, Colored barley, Silage, Fermentative quality)

\section{I . INTRODUCTION}

Anthocyanins are natural pigments belonging to the flavonoid group. They are widely distributed in flowers, fruits, vegetables, and several crops. Studies on anthocyanins have been actively conducted since their biological functions and usage for food coloring were confirmed by several researchers. The pigments were known to have functions such as antibacterial, antioxidant, anti-inflammatory action, heart disease prevention, and cancer cell growth inhibition (Seeram et al.,

Corresponding author: Tae Hwa Song, National Institute of Crop Science, RDA, Iksan, Korea.

Tel: +82-63-840-2145, Fax: +82-63-840-2116, E-mail: ocean0916@korea.kr 
2001; Katsuzaki et al., 2003; Hyun and Chung 2004; Fimognari et al., 2005; Chen et al., 2006). Due to the production of barley cultivation for whole crop silage in the winterseason rice field can be utilized as a promising way to enhance feed supply. Whole crop silage production can be an efficient way to use farm products as livestock feed and to increase farm income. Whole crop barley has been used as cattle feed in Korea, and a number of its cultivars are being used for silage (Park et al., 2008). Recently, meat consumption pattern in Korea is changing in terms of qualitative well-being, which requires the physiologically active substances, such as anthocyanins, in feed. Based on the domestic consumer's request and the effect of anthocyanins on livestock feed, we have studied colored barley with the aim of developing functional feed. Colored barley was developed as a food crop for human consumption, but its spikes and stems with a high content of anthocyanins were also suitable as a functional feed source for livestock (Song et al., 2012). To make silage with colored barley, Changes of anthocyanin content and the fermentation quality are very important. In addition, study on the stability of anthocyanins in the rumen is also needed because the rumen has a unique structure and function. Therefore, in this report we investigated the changes in fermentative quality of silage and anthocyanin content in whole crop of colored barley during both ensilage and in vitro incubation with ruminal fluid.

\section{П. MATERIALS AND METHODS}

\section{Silage making and analysis}

Boanchalbori (Hordeum valgare L.), a colored barley cultivar, and Yuyeonbori (Hordeum valgare L.), a normal barley cultivar, used in this study were developed at NICS, RDA, in Korea. The cultivars Boanchalbori and Yuyeonbori were harvested at the yellow ripe stage and cut into $2 \sim 3 \mathrm{~cm}$ long for making silage. The materials were prepared in a $15 \mathrm{~L}$ mini silo and then stored in a dark place at an ambient temperature $\left(15 \sim 20^{\circ} \mathrm{C}\right)$ for $2,4,6,12$ month, respectively. After ensiling, the crude protein (CP), neutral detergent fiber (NDF) and acid detergent fiber (ADF) were measured by the methods of AOAC (2000) and Van Soest et al. (1991). Total digestible nutrients (TDN) was calculated using the formula $\mathrm{TDN}(\%)=88.9-(0.79 \times \% \mathrm{ADF})$ (Holland, 1990). For the $\mathrm{pH}$ and organic acid analysis, the $10 \mathrm{~g}$ samples of silage ware mixed with $90 \mathrm{ml}$ pure water and extracted at $4^{\circ} \mathrm{C}$ in a shaking incubator for $24 \mathrm{hr}$. The extract which was passed through a syringe filter paper was used for $\mathrm{pH}$ and organic acid analyses. The $\mathrm{pH}$ and organic acid were determined by $\mathrm{pH}$ meter and high-performance liquid chromatography (HPLC), respectively. The anthocyanin content was extracted using 0.01 NHCl- $80 \%$ Methanol solution and determined by spectrophotometer and HPLC. The HPLC conditions for the analysis of anthocyanins were shown in Table 1.

\section{In vitro ruminant fermentation}

Ruminal fluid was obtained from slaughtered fresh rumen of healthy Hanwoo (Korean cattle) at the slaughter house and was pre-heated at $38^{\circ} \mathrm{C}$. The fluids were passed through 4 layers of cheesecloth in pour fluids in Erlenmeyer flask an equal volume. Culture fluid was prepared by ruminal fluid and buffers (Table 2), which was preliminarily purged with $\mathrm{CO}_{2}$ gas (Marten and 
Table 1. HPLC conditions for the analysis of anthocyanins

\begin{tabular}{cc}
\hline Items & Condiions \\
\hline \hline Column & YMC-Pack ODS-AM \\
Detector & UV, $520 \mathrm{~nm}$ \\
Flow rate & $0.9 \mathrm{ml} / \mathrm{min}$ \\
Solvent & A: $5 \%$ formic acid \\
& B: Acetonitrile + formic acid \\
Absorbance & $520 \mathrm{~nm}$ \\
Injection volume & $10 \mathrm{ul}$ \\
\hline
\end{tabular}

Barnes, 1980). In vitro incubation was performed in a glass tube containing $1 \mathrm{~g}$ of colored barley silage with $50 \mathrm{ml}$ of culture fluid for $0,6,12$, 24 and $48 \mathrm{~h}$. The tube was kept at $38^{\circ} \mathrm{C}$ in a shaking incubator and purged continuously with $\mathrm{CO}_{2}$ gas. After incubation, the fermentation was stopped by sinking the tube into ice-cold water and the $\mathrm{pH}$ of the fluid was measured. The content of the tube were lyophilized for the anthocyanin assay.

\section{Statistical analysis}

The data of this experiment was subjected to SAS Ver. 9.1 program and statistically significant differences among means were determined using Duncan's multiple range testat $5 \%$ probability (SAS, 2002).

\section{RESULTS AND DISCUSSION}

\section{Feed value of silage}

Changes in the feed value of silage after ensiling were shown in Table 3. Crude protein in both the silages tended to be increased up to 2 months of ensiling and thereafter maintained at a similar level. NDF and ADF contents of both the silages were increased significantly up to 2 months of ensiling $(\mathrm{p}<0.05)$, but they were maintained at the constant level after 2 months of ensiling. However, TDN content was decreased until 2 months of ensiling $(\mathrm{p}<0.05)$, then maintained at a stable level. In the colored barley silage, crude protein content was significantly higher than that of the normal barley silage $(p<0.05)$. However, NDF and ADF contents were similar with the control silage. Heo et al. (2005) reported that ensiling of winter cereal crops reduced moisture content, but increased the content of crude protein, NDF and ADF. Cottyn et al. (1985) also reported that ensiling increased the content of crude protein and crude fiber but decreased NFE content. We would be assumed that such an increase in the content of crude protein and fiber could be induced by the fermentation of soluble carbohydrates.

\section{Fermentation quality of silage}

Table 2. Sources of buffer used in this experiment

\begin{tabular}{cc|cc}
\hline Buffer solution A & g/liter & Buffer solution B & g/liter \\
\hline \hline $\mathrm{KH}_{2} \mathrm{PO}_{4}$ & 10.0 & $\mathrm{Na}_{2} \mathrm{CO}_{3}$ & 15.0 \\
$\mathrm{MgSO}_{4} \cdot 7 \mathrm{H}_{2} \mathrm{O}$ & 0.5 & $\mathrm{Na}_{2} \mathrm{~S}_{2} \mathrm{O}$ & 1.0 \\
$\mathrm{NaCl}$ & 0.5 & & \\
$\mathrm{CaCl}_{2} \cdot 2 \mathrm{H}_{2} \mathrm{O}$ & 0.1 & & \\
Urea & 0.5 & & \\
\hline
\end{tabular}


Table 3. Changes in percent CP, NDF, ADF and TDN according to ensiling period in colored barley and normal barley silage

\begin{tabular}{|c|c|c|c|c|c|}
\hline Cultivar & $\begin{array}{l}\text { Month after ensiling } \\
\text { (month) }\end{array}$ & $\begin{array}{l}\mathrm{CP}^{1)} \\
(\%)\end{array}$ & $\begin{array}{l}\text { NDF } \\
(\%)\end{array}$ & $\begin{array}{l}\text { ADF } \\
(\%)\end{array}$ & $\begin{array}{l}\text { TDN } \\
(\%)\end{array}$ \\
\hline \multirow{6}{*}{$\begin{array}{l}\text { Colored barley } \\
\text { (Boanchal) }\end{array}$} & 0 & 8.4 & $444.3^{b}$ & $23.6^{\mathrm{b}}$ & $70.2^{\mathrm{a}}$ \\
\hline & 2 & 9.0 & $50.9^{\mathrm{a}}$ & $27.7^{\mathrm{a}}$ & $67.0^{\mathrm{b}}$ \\
\hline & 4 & 8.9 & $51.2^{\mathrm{a}}$ & $29.0^{\mathrm{a}}$ & $66.0^{\mathrm{b}}$ \\
\hline & 6 & 9.2 & $49.1^{\mathrm{a}}$ & $27.6^{\mathrm{a}}$ & $67.1^{\mathrm{b}}$ \\
\hline & 12 & 9.0 & $50.7^{\mathrm{a}}$ & $27.8^{\mathrm{a}}$ & $66.9^{\mathrm{b}}$ \\
\hline & Mean & $8.9^{\mathrm{A}}$ & 49.2 & 27.1 & 67.4 \\
\hline \multirow{6}{*}{$\begin{array}{c}\text { Normal barley } \\
\text { (Yuyeon) }\end{array}$} & 0 & 8.1 & $44.0^{b}$ & $23.6^{\mathrm{b}}$ & $70.2^{a}$ \\
\hline & 2 & 8.3 & $50.6^{\mathrm{a}}$ & $28.9^{\mathrm{a}}$ & $66.1^{\mathrm{b}}$ \\
\hline & 4 & 8.2 & $51.7^{\mathrm{a}}$ & $28.8^{\mathrm{a}}$ & $66.1^{\mathrm{b}}$ \\
\hline & 6 & 8.3 & $46.1^{\mathrm{a}}$ & $27.5^{\mathrm{a}}$ & $67.2^{\mathrm{b}}$ \\
\hline & 12 & 8.5 & $47.3^{\mathrm{a}}$ & $27.2^{\mathrm{a}}$ & $67.5^{\mathrm{b}}$ \\
\hline & Mean & $8.3^{\mathrm{B}}$ & 47.9 & 27.2 & 67.4 \\
\hline
\end{tabular}

${ }^{\mathrm{a}, \mathrm{b}}$ Treatments with different letters are different at $\mathrm{p}<0.05$.

${ }^{1)} \mathrm{CP}$ : crude protein, NDF : neutral detergent fiber, ADF : acid detergent fiber, TDN : total digestible nutrients.

Changes in the fermentation quality of colored and normal barley silage during ensiling period were shown in Table 4. Although $\mathrm{pH}$ values of both the silages was decreased gradually during ensiling period, the value was maintained around 4.0. Butyric acid was not detected. In the colored barley silage, the $\mathrm{pH}$ value showed slightly lower than the normal barley silage but not significant, and lactic acid content was significantly higher than the normal barley silage $(\mathrm{p}<0.05)$. According to the pervious review (Charmley, 2000), factors such as water soluble carbohydrate, moisture, buffering capacity, type of bacteria which predominate, packing and sealing are known to beassociated with silage fermentation during ensiling period. In this report, colored barley and normal barley silage were all shown good quality in during ensiling period.

\section{Anthocyanin content in silage fermentation}

Changes in anthocyanin content of colored barley silage during ensiling period were shown in Fig. 1, 2 and Table 5. In Fig. 1, total anthocyanin content of colored barley silage deceased after ensiling and it was significantly lower than the raw material for the whole period of ensiling $(\mathrm{p}<0.05)$. The total anthocyanin content in the whole crop colored barley silage decreased to $42 \%$ after 2 months of ensiling, but it maintained at a constant level until 12 months of ensiling. In case of anthocyanin compositions (Table 5), cyaniding-3-glucoside (C3G) and malvidin-3-gluciside (M3G) contents were significantly decreased after 2 months of ensiling $(\mathrm{p}<0.05)$, but they were maintained at a constant level after 2 months of ensiling. Perlargonidin-3glucoside (P3G) and delphinidin (Del) contents 
Table 4. Change in fermentative quality according to ensiling period in colored barley silage

\begin{tabular}{|c|c|c|c|c|c|c|}
\hline \multirow{2}{*}{ Variety } & \multirow{2}{*}{$\begin{array}{l}\text { Month after ensiling } \\
\text { (month) }\end{array}$} & \multirow{2}{*}{$\mathrm{pH}$} & \multicolumn{4}{|c|}{ Organic acid $\left(\%, \mathrm{DM}^{1)}\right)$} \\
\hline & & & Lactic acid & Acetic acid & Propionic acid & Butyric acid \\
\hline \multirow{5}{*}{$\begin{array}{l}\text { Colored barley } \\
\text { (Boanchal) }\end{array}$} & 2 & 4.3 & 4.98 & 1.38 & 0.02 & 0.0 \\
\hline & 4 & 4.1 & 5.22 & 1.25 & 0.04 & - \\
\hline & 6 & 4.1 & 5.21 & 1.30 & 0.03 & - \\
\hline & 12 & 4.0 & 5.19 & 1.32 & 0.02 & - \\
\hline & Mean & 4.1 & $5.15^{\mathrm{A}}$ & 1.31 & 0.03 & - \\
\hline \multirow{5}{*}{$\begin{array}{c}\text { Normal barley } \\
\text { (Yuyeon) }\end{array}$} & 2 & 4.5 & 4.36 & 1.41 & 0.03 & 0.0 \\
\hline & 4 & 4.3 & 4.61 & 1.29 & 0.05 & - \\
\hline & 6 & 4.2 & 4.83 & 1.26 & 0.04 & - \\
\hline & 12 & 4.2 & 4.78 & 1.38 & 0.05 & - \\
\hline & Mean & 4.3 & $4.65^{\mathrm{B}}$ & 1.34 & 0.04 & - \\
\hline
\end{tabular}

A, B Treatments with different letters are different at $\mathrm{p}<0.05 .{ }^{1)} \mathrm{DM}$ : dry matter

-: Non detected.

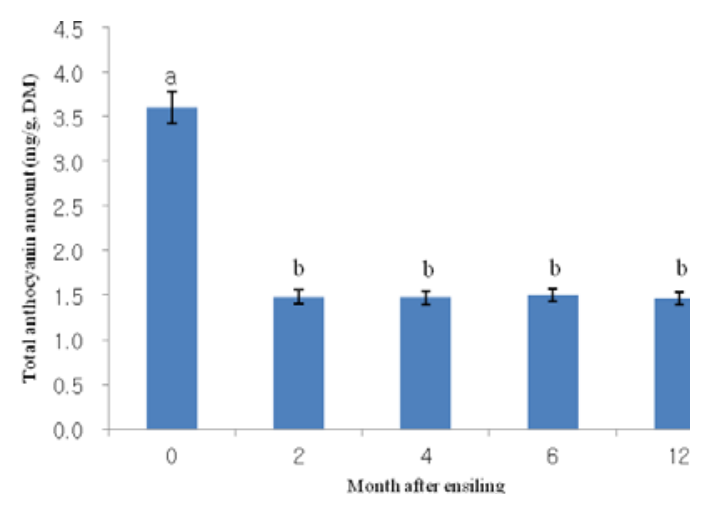

Fig. 1. Change in total anthocyanin content after ensiling of colored barley.

${ }^{\mathrm{a}, \mathrm{b}}$ Treatments with different letters are different at $\mathrm{p}<0.05$.

were maintained at similar levels, and cyaniding (Cya), pelargonidin (Pel), peonidin (Peo), and malvidin (Mal) contents were not detected from 2 months of ensiling. There were many factors affecting the stability of anthocyanin the factors, oxygen, light, high temperature, and high $\mathrm{pH}$ were associated with anthocyanin stability during ensiling period (Francis, 1989; Mazza and Miniati, 1993). In this study, oxygen, light, and high

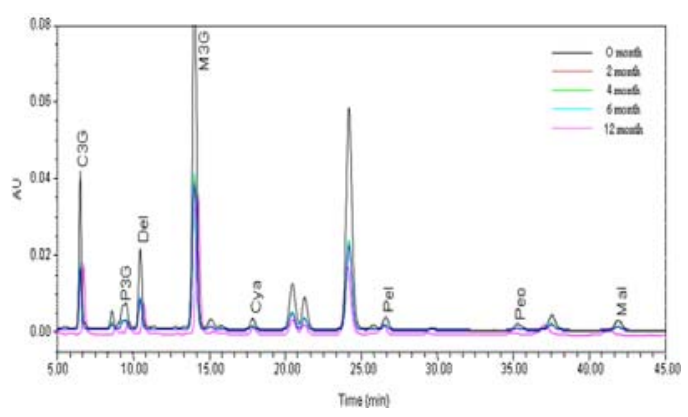

Fig. 2. Change of anthocyanins on the prolonged storing periods in colored barley silage.

temperature could not affect anthocyanin content during ensiling period because the silage kept in a mini silo was stored in a dark place at an ambient temperature. Cevallos-Casals and CisnerosZevallos (2004) reported that the $\mathrm{pH}$ affected anthocyanin stability in an extract form anthocyaninrich corn, and anthocyanin was degraded above $\mathrm{pH}$ 3. In this study, all silage was above $\mathrm{pH}$ 4.0 throughout the experiment, and therefore, decrease of anthocyanin content was attributed to the $\mathrm{pH}$ condition of the silage. Hosoda et al. 
Table 5. Change in anthocyanin composition after ensiling of colored barley

\begin{tabular}{cccccccccc}
\hline \multirow{2}{*}{$\begin{array}{c}\text { Month after ensiling } \\
\text { (month) }\end{array}$} & \multicolumn{9}{c}{ Anthocyanin content (mg/g) } \\
\cline { 2 - 8 } & C3G $^{1)}$ & P3G & Del & M3G & Cya & Pel & Peo & Mal & \\
\hline \hline 0 & $0.194^{\mathrm{a}}$ & 0.033 & 0.060 & $0.543^{\mathrm{a}}$ & 0.027 & 0.017 & 0.018 & 0.029 & $0.922^{\mathrm{a}}$ \\
2 & $0.096^{\mathrm{b}}$ & 0.028 & 0.041 & $0.229^{\mathrm{b}}$ & - & - & - & - & $0.393^{\mathrm{b}}$ \\
4 & $0.101^{\mathrm{b}}$ & 0.028 & 0.042 & $0.239^{\mathrm{b}}$ & - & - & - & - & $0.410^{\mathrm{b}}$ \\
6 & $0.103^{\mathrm{b}}$ & 0.029 & 0.042 & $0.244^{\mathrm{b}}$ & - & - & - & - & $0.418^{\mathrm{b}}$ \\
12 & $0.103^{\mathrm{b}}$ & $0.036^{\mathrm{b}}$ & $0.040^{\mathrm{b}}$ & $0.217^{\mathrm{b}}$ & - & - & - & - & $0.396^{\mathrm{b}}$ \\
\hline
\end{tabular}

${ }^{\mathrm{a}, \mathrm{D}}$ Treatments with different letters are different at $\mathrm{p}<0.05$.

${ }^{1)}$ C3G : cyanidin-3-glucoside, P3G : pelargonidin-3-glucoside, Del : delphinidin, M3G : malvidin3-O-glucoside, Cya : cyanidin, Pel : pelargonidin, Peo : peonidin, Mal : malvidin. - : Non detected.

(2009) reported that the relationship between anthocyanin stability and lactic fermentation was determined during ensiling period, and also proposed a possibility that the sugars of anthocyanin was used as substrate for lactic fermentation because anthocyanin was composed of anthocyanidin and sugars. A further study is still needed on the changes of anthocyanin content during ensiling period.

\section{Anthocyanin stability in in vitro ruminal fluid digestion}

Changes in anthocyanin content of colored barley during in vitro ruminal digestion were presented in Fig. 3. The $\mathrm{pH}$ value of ruminal fluid was decreased significantly after 12 hours of incubation and the anthocyanin content was maintained at a similar level during incubation. Our results were similar to those of Hosoda et al. (2009) that the incubation of anthocyanin-rich corn with ruminal fluid did not cause degradation of the anthocyanin. According to the reviews on anthocyanin absorption (Miyazawa et al., 1999; Passamonti et al., 2003), anthocyanin was absorbed in the stomach and guts in the human and rats and then detected in the blood.

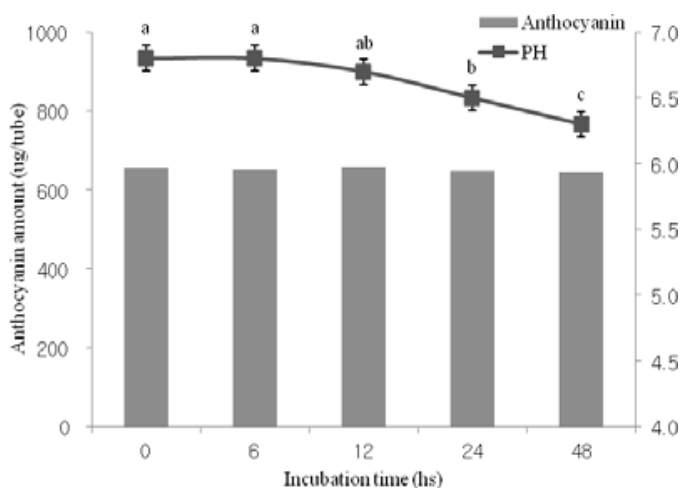

Fig. 3. Changes in anthocyanin of colored barley content during in vitro ruminal digestion.

${ }^{a, b, c}$ Treatments with different letters are different at $\mathrm{p}<0.05$.

The rumen has a unique structure and function.

The digestion and absorption function in the abomasums and intestines of ruminants are analogous to the alimentary canal of monogastric animals (Dijkstra et al., 2005). Therefore, it could be suggested that anthocyanin would have the potential to be used for ruminants as long as its composition is stable in the rumen.

Our results indicated that anthocyanin had no negative effect on silage fermentation, and its content was lowered down to $42 \%$ but maintained stable during the entire ensiling period. Whole 
crop colored barley showed a good fermentation quality, and its anthocyanin content was not affected in the ruminal fluid. Therefore, our results would suggest that whole crop colored barley could be used as a functional feed for ruminants.

\section{ACKNOLEDGEMENTS}

This study was supported by a Postdoctoral Fellowship Program of National Institute of Crop Science (NICS), Rural Development Administration (RDA), Republic of Korea, and a grant from "Cooperative Research Program for Agricultural Science \& Technology Development (Project No. PJ007435)”, RDA, Republic of Korea.

\section{REFERENCES}

AOAC. 2000. Official methods of analysis of AOAC International, 17th eds. AOAC International, Gaithersburg, MD. Cevallos-Casals, B.A. and Cisneros-Zevallos, L. 2004. Stability of anthocyaninbased aqueous extracts of Andean purple corn and red-fleshed sweet potato compared to synthetic and natural colorants. Food Chemistry. 86:69-77.

Charmley, E. 2000. Towards improved silage quality-A review. Crops and Livestock Research Centre, Agriculture and Agri-Food Canada, Nappan, Nova Scotia, Canada B0L 1C0.

Chen, P.K., Chu, S.C., Chiou, H.L., Kou, W.H., Chiang, C.L. and Hsieh, Y. S. 2006. Mulberry anthocyanins, cyanidin-3-rutinoside and cyanidin-3glucoside, exhibited and inhibitory effect on the migration and invasion of a human lung cancer cell line. Cancer Letters. 235:248-259.

Cottyn, B.G., Boucque, C.H.V., Fiems, L.O., Vanacker, J.M. and Buysse, F.X. 1985. Unwilted and prewilted grass silage for finishing bulls. Grass and Forage Science. 40:119-125.

Dijkstra, J., Forbes, J.M. and France, J. 2005. Introduction. In: Quantitative aspects of ruminant digestion and metabolism, 2nd Ed. (Ed. J.
Dijkstra, J. M. Forbes and J. France). CABI Publishing, Wallingford, UK. pp. 1-10.

Fimognari, C., Berti, F., Nusse, M., Forti, G.C. and Hrelia, P. 2005. In vitro antitumor activity of cyanidin-3-O- $\beta$-glucopyranoside. Chemotheraphy. 51:332-335.

Francis, F. 1989. Food colourants: Anthocyanins. Critical. Reviews in Food Science and Nutrition. 28:273-314.

Heo, J.M., Lee, S.K., Lee, I.D., Lee, B.D. and Bae, H.C. 2005. Effect of different growing stages of winter cereal crops on the quality of silage materials and silages. Journal of Animal Science and Technology. (Korea.) 47(5):877-890.

Holland, C., Kezar, W., Kautz, W.P., Lazowski, E.J., Mahanna, W.C. and Reinhart, R. 1990. Pioneer Hi-Bred Intemational, Inc., Des moines, IA.

Hosoda K., Eruden, B., Matsuyama, H. and Shioya, S. 2009. Silage fermentative quality and characteristics of anthocyanin stability in anthocyanin- rich corn (Zea mays L.). Asian-Aust. Journal of Animal Science. 22(4):528-533.

Hyun, J.W. and Chung, H.S. 2004. Cyanidin and malvidin from Oryza sativa cv. Heugjinju-byeo mediate cytotoxicity against human monocytic leukemia cells by arrest of $\mathrm{G}(2) / \mathrm{M}$ phase and induction of apoptosis. Journal of Agricultural and Food Chemistry. 52:2213-2217.

Katsuzaki, H., Hibasami, H., Ohwaki, S., Ishikawa, K., Imai, K., Date, K., Kimura, Y. and Komiya, T. 2003. Cyanidin-3-O- $\beta$-D-glucoside isolated from skin of black Glycine max and other anthocyanins isolated from skin of red grape induce apoptosis in human lymphoid leukemia Molt 4B cells. Oncology Reports. 10:297-300.

Mazza, G. and Miniati, E. 1993. Anthocyanins in fruits, vegetables and grains. CRC Press, Boca Raton, FL.

Marten, G.C. and Barnes, R.F. 1980. Prediction of energy digestibility of forages with In vitro rumen fermentation and fungal enzyme systems, in standardiztion of analytical methodology for feeds. Proceedings of a workshop held in Ottawa, Canada. Ottawa, Ont. IDRC.

Miyazawa, T., Nakagawa, K., Kudo, M., Muraishi, K. and Someya, K. 1999. Direct intestinal absorption of 
red fruit anthocyanins, cyanidin-3-glucoside and cyanidin-3,5-diglucoside, into rats and humans. Journal of Agricultural and Food Chemistry. 47: 1083-1091.

Passamonti, S., Vrhovsek, U., Vanzo, A. and Mattivi. F. 2003. The stomach as a site for anthocyanins absorption from food. FEBS Lett. 544(1-3):210-3.

Park, T.L., Han, O.k., Seo, J.H., Choi, J.S., Park, K.H. and Kim, J.G. 2008. New barley cultivars whit improved morphological characteristics for whole crop forage in Korea. Journal of the Korean Society of Grassland and Forage Science. 28(3):193-202.

SAS. 2002. SAS system Releas 9.1, SAS Institute Inc., Cary, NC.

Seeram, N.P., Momin, R.A., Nair, M.G. and Bourquin,
L.D. 2001. Cyclooxygenase inhibitory and antioxidant cyanidin glycosides in cherries and berries. phytomedicene. 8:362-369.

Song, T.H., Han, O.K., Park, T.I. Kim, Y.K., Kim, K.J. and Park, K.H. 2012. Effect of nitrogen top dressing levels on productivity feed value, and anthocyanin content of colored barley. Journal of the Korean Society of Grassland and Forage Science. 32(2):149-156.

Van Soest, P.J., Robertson, J.B. and Lewis, B.A. 1991. Methods for dietary fiber, neutral detergent fiber, and nonstarch polysaccharides in relation to animal nutrition. Journal of Dairy science. 74: 3583-3597.

(Received September 3, 2012/Accepted October 28, 2012) 